\title{
Elysia timida (Risso, 1818) (Gastropoda, Opisthobranchia): relationship and feeding deterrence to a potential predator on the south-western Mediterranean coast
}

\begin{abstract}
The relationship between the sacoglossan Elysia timida and the ornate wrasse Thalassoma pavo was studied in two laboratory experiments using artificial models. A feeding-preference experiment was conducted to determine whether mollusc extract deterred feeding by T. pavo, by using a "realistic" mollusc model (imitating the colour pattern of E. timida) coated with mollusc extract, and a reference model (without imitation or extract), and fishes collected from two locations. It was observed that fish approached, attacked and ate more reference models than mollusc models. A second feeding-preference experiment was designed with four different coloured models: "realistic" (W), green $(\mathrm{G})$, red $(\mathrm{R})$ and chequered (S) pattern. Both fish populations clearly rejected the $\mathrm{S}$ model, and differed in their colour preferences. Although both populations seemed to prefer the R and $\mathrm{G}$ models equally, the $\mathrm{W}$ model was clearly rejected by the fish that coexist with the mollusc at one site (Mazarrón), but was not rejected by the other population of fish which does not coexist with it (Cabo de Palos). Mazarrón fishes would identify the $\mathrm{W}$ model with the presence of a toxic compound during their coexistence, and therefore avoid attacking conspicuously coloured E. timida models as a response to their visual signals. Therefore, it was concluded that extract of
\end{abstract}

Communicated by S.A. Poulet, Roscoff

F. Giménez-Casalduero ( $\square)$

Departamento de Ciencias Ambientales y Recursos Naturales, Universidad de Alicante, San Vicente del Raspeig, 03690 Alicante, Spain

E-mail: Francisca.Gimenez@ua.es

Tel.: + 34-965-903400

Fax: + 34-965-903815

C. Muniain

Museo Argentino de Ciencias Naturales "Bernardino Rivadavia", C1405DJR Buenos Aires, Argentina

J.A. García-Charton

Laboratoire d'Ichtyécologie Tropicale et Méditerranéenne, EPHE-UMR 8046 CNRS, Université de Perpignan, 66860 Perpignan cedex, France
E. timida is a deterrent for T. pavo, and its effect is sufficiently noxious that the fish tend to avoid it, so that the ability of the fishes to learn to recognise colours and identify certain colour patterns associated with obnoxious prey provides the molluscs the opportunity to survive by exhibiting a conspicuous coloration.

\section{Introduction}

The predator-prey relationship is one of the strongest selection factors in the evolution of behaviour (Csányi and Dóka 1993). Colour-pattern strategy (aposematism or crypsis), chemical defence and shelter background are prey adaptations to avoid predator pressure, while improved visual learning of specific patterns and detoxification ability are predator adaptations to counteract prey abilities (Krebs and Davies 1993). The visibility of an organism's colour pattern is affected not only by the inherent properties of the pattern, but also by predator vision, hunting tactics, prey behaviour, and the background colour patterns. The effects of these factors are not independent and may vary from place to place (Endler 1978). Bright coloration is often associated with distastefulness, since a conspicuous prey is easily recognised. Predators learn to avoid warning colours effortlessly, but having learned to avoid a prey type they are probably less likely to attack it by mistake if it is conspicuous (Guilford 1985).

It is frequently accepted that many marine molluscs use distasteful molecules to avoid attack by predator fishes. The opisthobranchs are shell-less molluscs with limited mobility and a broad variety of conspicuous coloration. During their evolution they have lost the mechanical protection given by the shell, but they have developed defensive strategies based on the use of chemical substances (Ros 1977; Rosenberg 1991). The principal source of chemical substances is their food; however, some opisthobranchs are able to modify chemical substances that have been sequestered from 
their prey or to biosynthesise them de novo (Cimino and Sodano 1993; Fontana et al. 1994).

The sacoglossan Elysia timida (Risso 1818) is a white Mediterranean opisthobranch that lives in well lit shallow waters characterised by low-energy hydrodynamic conditions. They are found in areas covered either by stones or a thick layer of sand. Such environments are also typical of the chlorophycean seaweed Acetabularia acetabulum (L.) (Marín and Ros 1992; Giménez-Casalduero 1999). This mollusc is able to biosynthesise de novo polypropionates, presumably as a chemical defence mechanism (Gavagnin et al. 1994a, b; Cimino and Ghiselin 1998). The ornate wrasse Thalassoma pavo L. is a labrid fish very common in south-western Mediterranean coastal regions (García-Charton and Pérez-Ruzafa 2001). It lives in the typical sacoglossan habitat, and feeds on small crustaceans and molluscs (Whitehead et al. 1986), and is therefore a potential predator of E. timida. It has been found that the different compounds isolated from this mollusc are toxic for the fish Gambusia affinis (commonly used for ecotoxicity tests), but it has not been demonstrated that the polypropionates deter predator fish that cohabit with the mollusc (see Gavagnin et al. 1994b).

The main objective of this paper is to demonstrate the capacity of E. timida to deter the marine fish $T$. pavo, and the effectiveness of the mollusc coloration as a warning signal. The mollusc extract and the acceptance of four coloured models (three of them based on the E. timida pattern, and the last one showing an "unrealistic" pattern) were tested for fish populations coming from two different locations in south-eastern Spain.

\section{Materials and methods}

Animal collection and fish-holding conditions

Using hand nets, the wrasses were collected from two localities on the coast of Murcia (south-eastern Spain) (Fig. 1): (1) at Cabo de Palos $\left(37^{\circ} 38^{\prime} \mathrm{N}, 0^{\circ} 41^{\prime} \mathrm{W}\right)$, where the predominantly rocky bottom is formed by boulders of different sizes with clumps of the seagrass
Posidonia oceanica interspersed in the rocky matrix;the sacoglossan is rare in this area, probably owing to the heavy wave action prevailing in this zone; (2) Mazarrón Bay $\left(37^{\circ} 33^{\prime} \mathrm{N}, 1^{\circ} 16^{\prime} \mathrm{W}\right)$, a coastal area protected from wave exposure where the sacoglossan and the seaweed Acetabularia acetabulum are particularly common and abundant (Marín and Ros 1992). The two areas are separated by $40 \mathrm{~km}$.

The fish were immediately transported to the laboratory, where they were placed in a tank containing a silica-sand substratum and flow-through well water $\left(20^{\circ} \mathrm{C}\right.$, salinity $\left.36 \%\right)$, and exposed to a 12-h light:12-h dark illumination regime. While in captivity, the fish were fed ad libitum two times daily with the same artificial food as that used in the experiments (described below).

The sacoglossan specimens were collected from Mazarrón Bay at depths of 1-3 m, and were transferred to the laboratory in an icebox within $3 \mathrm{~h}$.

\section{Artificial models}

The artificial sacoglossan models were based on previous experiments and were similar to those described by Magurran and Guirling (1986), Dugatkin and Godin (1992) and Giménez-Casalduero et al. (1999). Each model consisted of two parts: the main body and the outer skin. The main body was made from triturated sardine with $4 \%$ of carrageenan (Sigma 1013) (Fig. 2A, a). The ingredients were mixed by stirring and then heated in a microwave oven for $60 \mathrm{~s}$. The outer skin (Fig. 2A, b) was composed of two pieces of printed colour paper $0.7 \times 1.5 \mathrm{~cm}$ in size, created with a computer design programme. Five different designs were placed on the artificial diet: realistic $(W)$, coloured (R and $G)$, unrealistic (S) and control (X) models. W models were based upon the natural physical characteristics of E. timida (mollusc colour and design; Fig. 2A, W). In addition to this realistic model, two more models were made with the sacoglossan pattern but with different colours: the $\mathrm{R}$ model had red coloration (Fig. 2A, $R$ ), and the $\mathrm{G}$ model had green coloration (Fig. 2A, G). The "unrealistic" $\mathrm{S}$ model had a black-and-white chequered pattern (Fig. 2A,S). Finally, the X model had the same main body and size characteristics as previously, but the outer skin had no design on it, this model being used as a control in the chemical feeding-avoidance experiment (see below) (Fig. 2A, $X$ ).

To test the deterrent ability of E. timida, mollusc extract was used to coat the W models. Approximately 300 sacoglossans were collected in Mazarrón Bay and subsequently extracted in acetone, and the solvent evaporated under vacuum. The amount of extract used for each model was estimated according to Gavagnin et al. (1994a). The extract concentration was calculated as milligrams per gram dry weight of animal tissue, using an empirically derived equation for animal weight: $\mathrm{DW}=8.55 \mathrm{WW}+4.55 \times 10^{-4}(r=0.82)$, where DW is the dry weight and WW is the wet weight (both
Fig. 1 Fish-sampling sites in the south-western Mediterranean Sea. Asterisk Mazarrón; filled circle Cabo de Palos

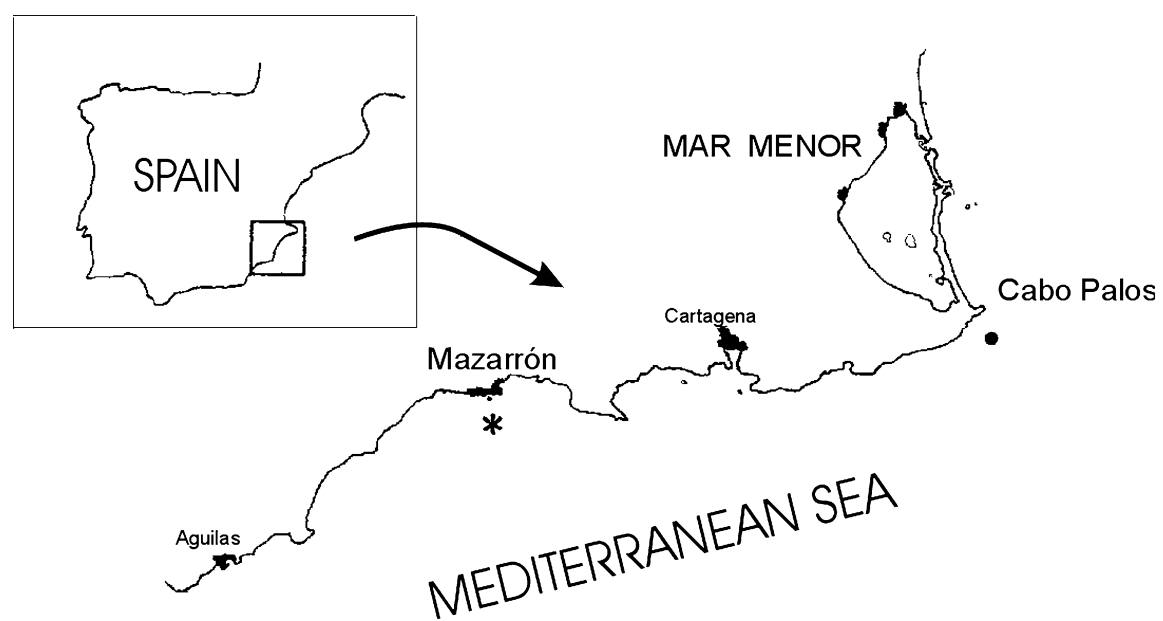




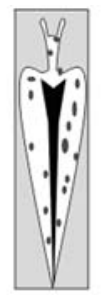

W

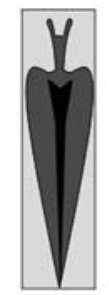

G

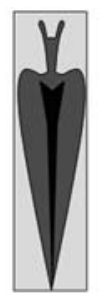

R

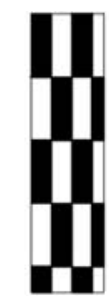

$S$
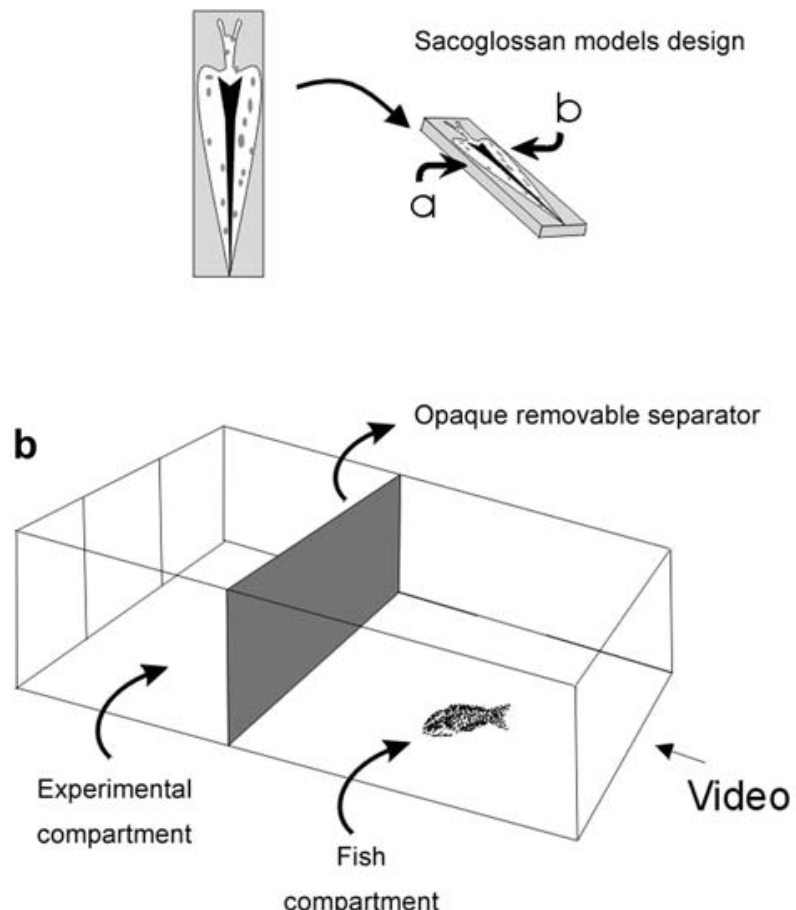

Fig. 2 A Design and coloration of artificial sacoglossan model ( $W$ white, realistic model; $G$ green, realistic model; $R$ red, realistic model; $S$ black-and-white chequered model; $X$ no-design model); $a$ main body of model made from triturated sardine with carragenan; $b$ outer skin of coloured model. B View of the aquarium showing the experimental and fish's compartment, the opaque removable separator and the position of the video camera

weights are in grams). This equation was used to calculate the concentration of extract used in each wet-weight model. Approximately $9.8 \times 10^{-4} \mathrm{~g}$ of extract was obtained for use for each $\mathrm{W}$ model. The extract was dissolved in ether and coated onto the $\mathrm{W}$ models.

\section{Experimental apparatus and video monitoring}

The experiments were conducted using a well illuminated tank $(110 \times 62 \times 40 \mathrm{~cm})$. The experimental tank, based on that used by Godin and Crossman (1994), was divided into two compartments (Fig. 2B). One compartment contained the fishes, and the other was equipped with hangers upon which the different artificial mollusc models could be placed. The compartments were separated from each other by a removable opaque partition, so that the fishes were not able to see the models prior to the start of the experiment. This opaque partition was raised prior to each trial, to allow the fish to enter the compartment containing the models. The tank was covered on three sides by light blue cardboard, and a video camera was installed on the fourth side. Videotapes were recorded continuously for $20 \mathrm{~s}$ after the removal of the partition. Tapes were analysed later by means of a video recorder.

\section{Chemical feeding-avoidance experiment}

To determine whether mollusc extract deterred feeding by T. pavo, a feeding-preference experiment was performed in the laboratory. $\mathrm{W}$-model and X-model molluscs were used, the former coated with mollusc extract, and the latter with ether. Each trial consisted of an equal number of each model: three $\mathrm{W}$ models and three $\mathrm{X}$ models were offered to five fishes at the same time during a 20 -s period. Eighteen trials were completed for each location, for a total of 36 trials. Data collected included the number of approaches, number of effective interactions (number of bites in each approach), and total number of fully-eaten models.

\section{Colour pattern preference experiment}

To measure the effectiveness of the colour pattern as a warning signal for fishes, a feeding-preference experiment was designed, based on Ritland (1994). W, R, G, and S models were tested. Eighteen individuals of $T$. pavo were independently tested in this experiment, nine from each locality. Each specimen of $T$. pavo was placed in the experimental tank, and two items of each model design were offered simultaneously to the fish during $20 \mathrm{~s}$. The total number of models eaten was scored for each trial.

\section{Data analysis}

To test for differences in behaviour between fishes from the two localities, arcsin-transformed data were compared using a $t$-test (Underwood 1997) for both experiments. To compare the two populations, the measurements of the fishes' responses (approaches, effective interaction and number of models eaten) were tested independently. Also, the proportion of $\mathrm{W}$ models eaten relative to the total number of models eaten $[\mathrm{W} /(\mathrm{W}+\mathrm{G}+\mathrm{R}+\mathrm{S})]$ was analysed in the coloration-preference experiment.

Analysing each population independently, every experiment constituted a multi-choice assay, in which the consumption of one type of model was not independent of the consumption of another type of model. The data were analysed by the one-sample Hotelling's $T^{2}$ test (Roa 1992; Giménez-Casalduero et al. 1999). This multivariate-analysis technique is applicable in the situation in which $p$ food types are offered to the fish in the tank (in the feedingavoidance experiment, $p=2$ and $n=18$; in the coloration-preference experiment, $p=4$ and $n=9$ ), so that the response variable in such an experiment is a vector $X$ of mean consumptions of dimension $p$, in which the components (the different models) are correlated. The null hypothesis to be tested for both experiments was that the consumer has no food preference, which is equivalent to testing whether the components of the mean vector $X$ are all equal to a constant $k$ (the overall mean). The statistical test to prove this hypothesis is Hotelling's statistic $T^{2}=n(X-k)^{\prime} \mathrm{S}^{-1}(X-k)$, where $\mathrm{S}^{-1}$ is the inverse of the sampling variance-covariance matrix, and $(X-k)$ is the vector of differences between the sample means and the hypothesised constant. When the null hypothesis is true, $F=\{[(n-p) /$ $(p(n-1)]\} T^{2}$ has the $F$ distribution with $p$ and $n-p$ degrees of freedom. When the null hypothesis of "no preference" is rejected, those food types with means greater than the constant $k$ (no preference) are suspected to be preferred; and the opposite is true for foods with means less than $k$. Data were centred on zero by subtracting the constant $k$ from each datum in order to simplify the identification of preferred and rejected food types, so that the null hypothesis of no preference in this case is whether the components of the mean vector are equal to zero. Since no autogenic changes are expected to occur in the absence of consumers during the experiments, controls were not included (Roa 1992; Manly 1993). The use, as dependent variables, of quantities (number of approaches, number of bites and number of models eaten) that estimate 
absolute rather than relative consumption precludes use of the alternative analysis proposed by Lockwood (1998).

\section{Results}

Chemical feeding avoidance

Behaviour towards $\mathrm{W}$ models did not show significant differences between the two fish populations in respect of either the number of approaches $(t=0.3, P>0.05)$, the number of effective interactions $(t=0.6, P>0.05)$, or the number of models eaten $(t=0.5, P>0.05)$ (Fig. 3). The extract used on the $\mathrm{W}$ model seemed to cause rejection by the fishes, since fishes coming from both populations rejected the $\mathrm{W}$ models equally for all the parameters examined in the present study. In addition, when each population was analysed independently, we observed that the $\mathrm{W}$ models were less inspected than the X models by both $T$. pavo populations, and that the number of approaches to $\mathrm{W}$ models was found to be
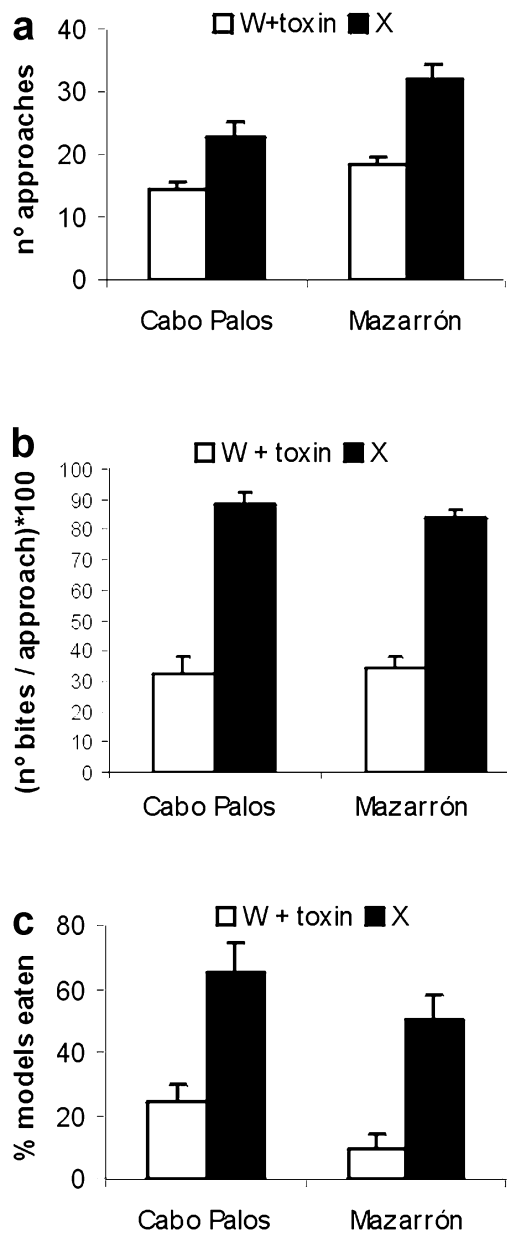

Fig. 3 Mean values ( \pm SE) of fish approaches (a), percentage of models bitten in relation to the total number of fish approaches (b), and percentage of models eaten by fish (c) in both populations of Thalassoma pavo. White columns $\mathrm{W}+$ toxin: Elysia timida model impregnated with sacoglossan extract; black columns X: no-design model impregnated with ether significantly lower. For each approach to a W model, fishes captured at Cabo de Palos made, on average, 1.6 approaches to an $\mathrm{X}$ model, and fishes from Mazarrón made, on average, 1.8 approaches to an $\mathrm{X}$ model (Cabo de Palos: $T^{2}=0.65, F_{2,16}=5.19, P<0.05$; Mazarrón: $T^{2}=1.75, \quad F_{2,16}=13.98, \quad P<0.001$ ) (Table 1; Fig. 3). Furthermore, the number of effective interactions (number of bites relative to number of approaches) was lower for the realistic $\mathrm{W}$ models than for the $\mathrm{X}$ models for each population (Cabo de Palos: $T^{2}=6.38$, $F_{2,16}=51.00, \quad P<0.001 ; \quad$ Mazarrón: $T^{2}=6.40, \quad F_{2,16}$ $=51.16, P<0.001)($ Table 1; Fig. 3). Fishes were rather efficient with respect to $X$ models, since $80-90 \%$ of approaches resulted in bites, this effectiveness being lower for $\mathrm{W}$ models $(55 \%$ for the Cabo de Palos population and $49 \%$ for the Mazarrón population). The number of models eaten at the end of the experiment was similar to that seen for effective attacks, since fishes coming from both populations ate $41 \%$ more $\mathrm{X}$ models than $\mathrm{W}$ models impregnated with toxin (Cabo de Palos: $T^{2}=1.36, F_{2,16}=10.88, P<0.001 ;$ Mazarrón: $T^{2}=1.40$, $\left.F_{2,16}=11.16, P<0.001\right)$ (Table 1; Fig. 3).

\section{Coloration preferences}

Fish behaviour towards W models was compared between the two populations using the number of $\mathrm{W}$ models eaten relative to the total number of models eaten each time. The results showed that the population cohabiting with the mollusc, at Mazarrón, rejected the W model, whereas the population from Cabo de Palos did not (Fig. 4; Student's $t=2.7, P<0.05$ ).

Both fish populations clearly rejected the chequerboard design of the S model: the Mazarrón population ate only $11 \%$ of these models, and the Cabo de Palos fishes, only $28 \%$ (Table 2; Fig. 4). In addition, fishes from Cabo de Palos and from Mazarrón differed as to their colour preferences. Both populations preferred the $\mathrm{R}$ and $\mathrm{G}$ models equally, but the $\mathrm{W}$ model was clearly rejected by only the Mazarrón fishes (Table 2). The Mazarrón population ate the $\mathrm{R}$ and $\mathrm{G}$ models with the same intensity ( $94 \%$ of models eaten), but the proportion of $\mathrm{W}$ models eaten was found to be $39 \%$, an intermediate value between the $\mathrm{S}$ model in one part, and the $\mathrm{R}$ and $\mathrm{G}$ models in the other part $\left(T^{2}=34.66\right.$, $\left.F_{4,5}=43.33, P<0.001\right)$. The Cabo de Palos fishes consumed the $\mathrm{W}$ model with the same intensity as they did the $\mathrm{R}$ and $\mathrm{G}$ models $\left(T^{2}=17.11, F_{4,5}=21.39, P<0.01\right)$ (Table 2; Fig. 4).

\section{Discussion}

The identification of external signals by fish through chemoreceptors can be achieved by odour, taste or chemoreceptive epidermal cells (Baatrup and Doving 1985; Peters et al. 1987, 1990, 1991; Kotrschal 1991). The capacity to recognise odour in the aquatic environment 
Table 1 Results of Hotelling's $T^{2}$ test on number of fish approaches, of effective attacks and of models eaten in feeding-preference experiments on Thalassoma pavo from Mazarrón and from Cabo de Palos in respect of the colour-pattern and chemical feeding preference experiments; $W+$ toxin: Elysia timida model impreg-

\begin{tabular}{|c|c|c|c|c|c|c|c|c|}
\hline \multirow[t]{2}{*}{ Approaches } & Population & No. & Centred mean & & $T^{2}$ & $d f$ & $F$ & $P$ \\
\hline & Mazarrón & 18 & -6.833 & 6.834 & 1.75 & 2,16 & 13.98 & $<0.001$ \\
\hline \multirow[t]{2}{*}{ Effective attacks } & $\begin{array}{l}\text { Cabo de Palos } \\
\text { Population }\end{array}$ & $\begin{array}{l}18 \\
\text { No. }\end{array}$ & $\begin{array}{l}-4.306 \\
\text { Centred means }\end{array}$ & 4.305 & $\begin{array}{l}0.65 \\
T^{2}\end{array}$ & $\begin{array}{l}2,16 \\
d f\end{array}$ & $F^{5.19}$ & $\begin{array}{l}<0.05 \\
P\end{array}$ \\
\hline & $\begin{array}{l}\text { Mazarrón } \\
\text { Cabo de Palos }\end{array}$ & $\begin{array}{l}18 \\
18\end{array}$ & $\begin{array}{l}\mathrm{W}+\text { toxin } \\
-0.248 \\
-0.278\end{array}$ & $\begin{array}{l}X+\text { ether } \\
0.248 \\
0.278\end{array}$ & $\begin{array}{l}6.40 \\
6.38\end{array}$ & $\begin{array}{l}2,16 \\
2,16\end{array}$ & $\begin{array}{l}51.16 \\
51.00\end{array}$ & $\begin{array}{l}<0.001 \\
<0.001\end{array}$ \\
\hline \multirow[t]{3}{*}{ Models eaten } & Population & No. & $\begin{array}{l}\text { Centred mean } \\
\mathrm{W}+\text { toxin }\end{array}$ & $X+$ ether & $T^{2}$ & $d f$ & $F$ & $P$ \\
\hline & Mazarrón & 18 & -0.610 & 0.612 & 1.40 & 2,16 & 11.16 & 0.001 \\
\hline & Cabo de Palos & 18 & -0.611 & 0.611 & 1.36 & 2,16 & 10.88 & 0.001 \\
\hline
\end{tabular}

nated with sacoglossan extract; $X+$ ether: no-design model impregnated with ether. Centred mean is the vector of differences between the sample means and the hypothesised constant overall mean, after centring on zero

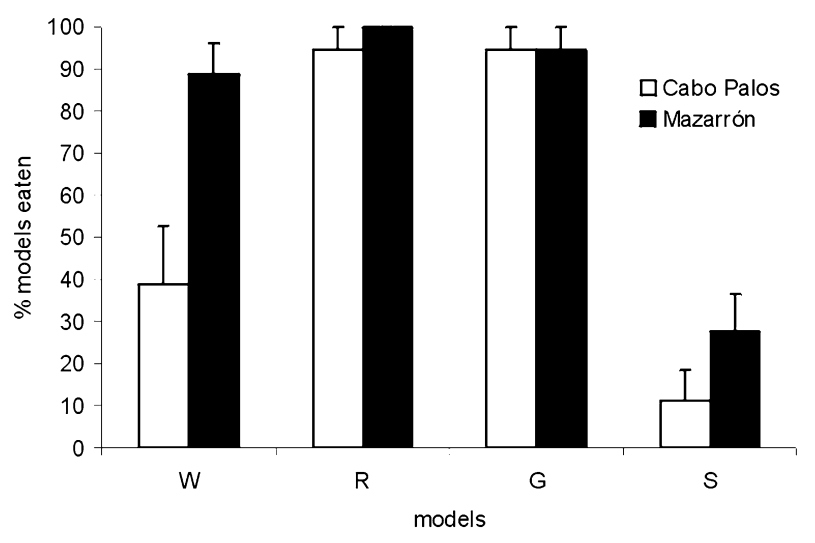

Fig. 4 Mean values $( \pm$ SE) of percentage of models eaten by $T$. pavo in both populations. $W$ E. timida model; $R$ red model; $G$ green model; $S$ black-and-white chequered model

has been evaluated for marine and freshwater species (Chivers and Smith 1993; Saglio and Blanc 1993; Valentinçiç et al. 1994). In accordance with the results of the present study, a rejection of the extract-coated realistic models exists even before tasting by both fish populations. Therefore, it would seem as if a repellent odour were coming from the mollusc extract. The differences between the $\mathrm{W}$ and the $\mathrm{X}$ models increased when the effective attack of both populations was analysed. Fishes bit the $\mathrm{W}$ model less than they did the $\mathrm{X}$ model: this could be the synergic effect of repellent odour and bad taste of E. timida extract. The tastings, and subsequent rejections, of the $\mathrm{W}$ model were $41 \%$ higher than those for the $\mathrm{X}$ models. As a consequence of these results, it could be concluded that the individuals of E. timida are deterrent preys for T. pavo, and their effect is sufficiently noxious for the fish to tend to avoid them.

Some sacoglossans have adapted to feeding upon chemically defended plants (Marín and Ros 1989; Paul et al. 1982, 1992), presumably because they avoid predation and incidental ingestion by macroherbivores, or because they sequester secondary metabolites from these seaweeds, which then protect them from their own

predators (Hay 1991). For its part, E. timida feeds on host plants, for example Acetabularia acetabulum, that do not contain deterrent metabolites, and therefore it must synthesise its own defence. Ireland and Scheuer (1979) discovered the polypropionate photodeoxytridachione and 9,10-deoxytridachione in the Pacific sacoglossan Placobranchus ocellatus, a metabolic product that is also found in E. timida. Furthermore, E. timida contains the polypropionates 15-norphotodeoxytridachione and iso-9,10-deoxytridachione, chemicals that are ejected in the event of an alarm (Gavagnin et al. 1994b), and found exclusively in this Mediterranean mollusc. For another example, Elysia viridis feeds upon Codium vermilara, which is protected by elysione that is synthesised de novo with a high level of incorporation of propionate (Gavagnin et al. 1994a; Cimino et al. 1999). Muniain et al. (1999) mentioned a non-characterised polypropionate from the mantle of the south Atlantic species Elysia patagonica, recently described by Muniain and Ortea (1997). The sacoglossan lives on the green alga Bryopsis plumose, from which it sequesters intact chloroplasts in the vacuoles of its digestive cells. The presence of chemical metabolites only appears to be associated with this mollusc (Muniain et al. 2001). The presence of the same molecules in species from distinct geographical areas suggests an effective defensive role of these polypropionates against different potential predators in several marine ecosystems, but it has only been demonstrated in the laboratory in a few cases. Generalist herbivores feed on a wide variety of plants and so become more widely dispersed in space. The selective pressure exerted by natural predators might have resulted in the evolution of de novo defences (Hay 1991; Cimino et al. 1999).

The results obtained in the test of coloration preferences seem to indicate that the wrasse $T$. pavo, regardless of its origin, can discriminate mollusc colour and reject a disruptive colour pattern (model S). The disruptive color pattern consists of a design that breaks the visual contour of the animal, causing the animal to integrate visually into its background elements, but without formal 
Table 2 Results of Hotelling's $T^{2}$ test on data from feeding-preference experiments on $T$. pavo from Mazarrón and from Cabo de Palos in respect of the colour pattern preference experiment; $W E$. timida model; $R$ red model; $G$ green model; $S$ black-and-white chequered model. Centred mean is the vector of differences between the sample means and the hypothesised constant overall mean, after centring on zero

\begin{tabular}{|c|c|c|c|c|c|c|c|c|c|}
\hline \multirow[t]{2}{*}{ Population } & \multirow[t]{2}{*}{ No. } & \multicolumn{4}{|c|}{ Centred mean } & \multirow[t]{2}{*}{$T^{2}$} & \multirow[t]{2}{*}{$d f$} & \multirow[t]{2}{*}{$F$} & \multirow[t]{2}{*}{$P$} \\
\hline & & W & $\mathrm{R}$ & G & S & & & & \\
\hline Mazarrón & 9 & -0.417 & 0.694 & 0.694 & -0.972 & 34.66 & 4,5 & 43.33 & $<0.001$ \\
\hline Cabo de Palos & 9 & 0.250 & 0.361 & 0.361 & -0.972 & 17.11 & 4,5 & 21.39 & $<0.01$ \\
\hline
\end{tabular}

imitation of a concrete object. This conclusion is coincident with the results obtained in the experiments conducted by Ros (1981) using the disruptive design of the opistobranch Peltodoris atromaculata.

Sensory systems detect changes in the environment, with the transducer converting the physical signal of light/sound/pressure etc. into nerve impulse. "Experience" plays a role in determining the meaning of the input for visual processing (Lomas et al. 1998). Models based on E. timida pattern (W) caused different fish behaviour depending on the origin of the population. The Mazarrón population, which coexists with E. timida, rejected the realistic design imitating the mollusc pattern, while the Cabo de Palos population, which does not coexist with E. timida, presented a response to the $\mathrm{W}$ model similar to that for $\mathrm{G}$ and $\mathrm{R}$ models. Fishes captured in Mazarrón did not associate distastefulness with red and green colour, but they did with the realistic white colour pattern. Bearing in mind that the only difference between both fish populations was the habitat and the presence or not of sacoglossans in that habitat, the observed response of the Mazarrón $T$. pavo population is likely because these fishes have learned to avoid the E. timida colour pattern in their own habitat, by discriminating mollusc colours and associating the E. timida colour with noxiousness. The E. timida design seems to be a particularly optimum aposematic coloration design to avoid the fish attack. These results are in agreement with those of Giménez-Casalduero et al. (1999), who indicated that the common colours of nudibranchs are recognisable by fishes and can be associated with noxious prey. The observed differences in the behaviour of the Cabo de Palos fishes between the two experiments with respect to the $\mathrm{W}$ model could be attributed to the presence of the extract used in the feeding-avoidance experiment, instead of coloration or design. We cannot conclude that $T$. pavo can discriminate between green and red wavelengths.

Aposematic coloration is used by prey species to advertise noxious properties to potential predators, as opposed to cryptic coloration, in which the colour pattern of a prey ensures that a predator can not easily distinguish the prey from its background; the latter strategy is common in elysiids (for example, Bosellia mimetica, which feeds on Halimeda tuna and is truly indistinguishable; Marín and Ros 1989). Guilford (1990) provides four not mutually exclusive hypotheses to explain why organisms use conspicuousness for warning: (1) predators learn to associate distastefulness with conspicuous colour pattern more rapidly than with a cryptic colour pattern; (2) certain specific colour patterns are easier to associate with distastefulness than others; (3) new patterns are easier to learn; and (4) conspicuous coloration will allow fewer recognition errors than a cryptic one. Also, Edmunds (1991) gives four criteria by which to demonstrate that a mollusc is aposematic for a potential predator, if: (1) it is sufficiently noxious that the predator will not eat it; (2) it is conspicuously coloured; (3) the predators avoid attacking it because of its signals; (4) these conspicuous signals provide better protection to the individual or to its genes than other signals would. While many authors have generally accepted the existence of aposematic coloration in marine molluscs, these features have often been described only from a human perspective.

In summary, the present study shows experimental evidence of aposematism by E. timida against its potential predator $T$. pavo, after demonstrating that the sacoglossan polypropionates are effective deterrents for this fish species. Therefore, the ability of fishes to recognise colours and identify certain colour patterns with harmful prey allows the molluscs to survive by exhibiting a conspicuous coloration. Additional research is needed to measure the actual rate of predation avoidance by potential fish predators on E. timida under natural conditions in the field, thus estimating the relative importance of mortality due to predation for the population dynamics of this sacoglossan.

Acknowledgements We should like to thank A. Marín for providing space and facilities for completing this study. This research was supported by the research grant PN92 (Spanish National Programme of Researcher Training, Education and Science) to F.G.C., research grant INV01-56 from the Conselleria de Investigació (Generalitat Valenciana) in the University of Alicante to C.M., and a postdoctoral grant PD-01452/CV/00 (Fundación Séneca, Centro de Coordinación de la Investigación de la Comunidad Autónoma de la Región de Murcia) to J.A.G.C. The authors declare that the experiments complied with the current laws of the country in which the experiments were performed.

\section{References}

Baatrup E, Doving KB (1985) Physiological studies on solitary receptors of the oral disc papillae in the adult brook lamprey, Lampetra planeri (Bloch). Chem Senses 10:559-566 
Chivers DP, Smith RJF (1993) The role of olfaction in chemosensory-based predator recognition in the fathead minnow Pimephales promelas. J Chem Ecol 19:623-633

Cimino G, Ghiselin MT (1998) Chemical defence and evolution in the Sacoglossa (Mollusca: Gastropoda: Opisthobranchia). Chemoecology 8:51-60

Cimino G, Sodano G (1993) Biosynthesis of secondary metabolites in marine molluscs. Topics Curr Chem 167:77-115

Cimino G, Fontana A, Gavagnin G (1999) Marine opisthobranch molluscs: chemistry and ecology in sacoglossans and dorids. Curr Org Chem 3:327-372

Csányi V, Dóka A (1993) Learning interactions between prey and predator fish. Mar Behav Physiol 23:63-78

Dugatkin LA, Godin JGJ (1992) Predator inspection, shoaling and foraging under predation hazard in the Trinidadian guppy, Poecilia reticulata. Environ Biol Fish 34:265-276

Edmunds M (1991) Does warning coloration occur in nudibranchs? Malacologia 32:241-255

Endler JA (1978) A predator's view of animal colour patterns. Evol Biol 11:319-364

Fontana A, Giménez-Casalduero F, Marín A, Mollo E, Cimino G (1994). Transfer of secondary metabolites from the sponges Dysidea fragilis and Pleraplysilla spinifera to the mantle dermal formations (MDFs) of nudibranch Hypselodoris webbi. Experientia 50:510-516

García-Charton JA, Pérez-Ruzafa A (2001) Spatial pattern and the habitat structure of a Mediterranean rocky reef fish local assemblage. Mar Biol 138:917-934

Gavagnin M, Spinella A, Castellucio F, Cimino G, Marín A (1994a) Polypropionates from the Mediterranean mollusc Elysia timida. J Nat Prod 57:298-304

Gavagnin M, Marin A, Mollo E, Crispino A, Villani G, Cimino G (1994b) Secondary metabolites from Mediterranean Elysoidea: origin and biological role. Experientia 108B:107-115

Giménez-Casalduero F (1999) Estudio comparativo en diferentes poblaciones de Elysia timida (Risso, 1818) (Gastropoda: Opisthobranchia, Sacoglossa) en mar abierto y ambiente lagunar. Iberus 17:137-146

Giménez-Casalduero F, Thacker RW, Paul VJ (1999) Association of color and feeding deterrence by tropical reef fishes. Chemoecology 9:33-39

Godin JGJ, Crossman SL (1994) Hunger-dependent predator inspection and foraging behaviours in the threespine stickleback (Gasterosteus aculeatus) under predation risk. Behav Ecol Sociobiol 34:359-366

Guilford T (1985) Is kin selection involved in the evolution of warning coloration? Oikos 45:31-36

Guilford T (1990) The evolution of aposematism. In: Evans DS, Schmidt JO (eds) Insect defences. State University of New York Press, Albany, N.Y., pp 23-61

Hay ME (1991) The ecological ecology of plant-herbivore interactions in marine versus terrestial communities. In: Rosenthal GA, Berembaum MR (eds) Herbivores. Their interactions with secondary plant metabolites, vol II. Ecological and evolutionary processes. Academic Press, Harcourt Brace Jovanovich, New York, pp 372-414

Ireland C, Scheuer PJ (1979) Photosynthetic marine mollusks. In vivo ${ }^{14} \mathrm{C}$ incorporation into metabolites of the sacoglossan Placobranchus ocellatus. Science 205:922-923

Kotrschal K (1991) Solitary chemosensory cells - taste, common chemical sense or what? Rev Fish Biol Fish 1:3-22

Krebs JR, Davies NB (1993). An introduction to behavioural ecology. Blackwell Scientific, Oxford

Lockwood JR (1998) On the statistical analysis of multiple-choice feeding preference experiments. Oecologia 116:475-481

Lomas CA, Piggings D, Phillips CJC (1998) Visual awareness. Appl Anim Behav Sci 57:247-257
Magurran AE, Guirling SL (1986). Predator model recognition and response habituation in shoaling minnows. Anim Behav 34:510-518

Manly BFJ (1993) Comments on design and analysis of multiplechoice feeding-preference experiments. Oecologia 93:149-152

Marín A, Ros JD (1989). The chloroplast-animal association in four Iberian sacoglossans: Elysia timida, Elysia translucens, Thuridilla hopei and Bosellia mimetica. Sci Mar 53:429-440

Marín A, Ros JD (1992). Dynamics of a peculiar plant-herbivore relationship: the photosynthetic ascoglossan Elysia timida and the chlorophycean Acetabularia acetabulum. Mar Biol 112:677682

Muniain C, Ortea J (1997) First record of sacoglossan (= ascoglossan, Opisthobranchia) from Patagonia (Argentina): description of a new species of genus Elysia Risso, 1818. Veliger 40:29-37

Muniain C, Fontana A, Cimino G (1999). Estrategias defensivas en moluscos opistobranquios magallánicos. In: Guisado C (ed) Abstracts of the 4th Congreso Latinoamericano de Malacología (CLAMA), Coquimbo, Chile

Muniain C, Marín A, Penchaszadeh P (2001) Ultrastructure of the digestive gland of larval and adult stages of the sacoglossan Elysia patagonica. Mar Biol 139:687-695

Paul VJ, Sun HH, Fenical W (1982) Udoteal, a lineal diterpenoid feeding deterrent from tropical green alga Udotea flabellum. Phytochemistry 21:468-469

Paul VJ, Steinberg PD, Faulkner DJ, Pawlik JR (1992) Ecological roles of marine natural products. Comstock, Ithaca, N.Y.

Peters RC, Van Steenderen GW, Kotrschal K (1987) A chemoreceptive function for the anterior dorsal fin in rocklings (Gaidropsarus and Ciliata: Teleostei: Gadidae): electrophysiological evidence. J Mar Biol Assoc UK 67:819-823

Peters RC, Kotrschal K, Drautgartner WD, Atema J (1990) A novel chemosensory system in fish: electrophysiological evidence for mucus detection by solitary chemosensory cells in rocklings (Ciliata mustela: Gadidae). Biol Bull (Woods Hole) $177: 329$

Peters RC, Kotrschal K, Drautgartner WD (1991) Solitary chemoreceptor cell of Ciliata mustela (Gadidae, Teleostei). Chem Senses 16:31-42

Ritland DB (1994) Variation in palatability of queen butterflies (Danaus gilippus) and implications regarding mimicry. Ecology 75:732-746

Roa R (1992) Design and analysis of multiple-choice feedingpreference experiments. Oecologia 89:509-515

Ros JD (1977) La defensa en los opistobranquios. Invest Cienc $12: 48-60$

Ros JD (1981) Desarrollo y estrategias bionómicas en los opistobranquios. Oecol Aquat 5:147-183

Rosenberg G (1991) Aposematism and synergistic selection in marine gastropods. Evolution 45:451-454

Saglio P, Blanc JM (1993) Réponses comportamentales du brochet (Esox lucius L.) à un extrait épidermique de carassin doré (Carassius auratus L.) en olfactomètre. Bull Fr Pêche Piscicult 329:189-197

Underwood A (1997) Experiments in ecology. Their logical design and interpretation using analysis of variance. Cambridge University Press, Cambridge

Valentinçiç T, Wegert S, Caprio J (1994) Learned olfatory discrimination versus innate taste responses to amino acids in channel catfish (Ictalurus punctatus). Physiol Behav 55:865-873

Whitehead PJP, Bauchot ML, Hureau JC, Nielsen J, Tortonese E (1986) Fishes of the north-eastern Atlantic and the Mediterranean. UNESCO, Paris 